\title{
KEEFEKTIFAN KITOSAN DALAM MENGENDALIKAN Botryodiplodia theobromae Pat. PENYEBAB MATI PUCUK PADA BIBIT JABON (Anthocephalus cadamba (Roxb.) Miq)
}

\author{
Chitosan's Effectiveness in Controlling Dieback by Botryodiplodia theobromae Pat on \\ Jabon Seeding (Anthocephalus cadamba (Roxb. Miq)
}

\author{
Desi Nurafida ${ }^{1}$, Achmad $^{2}$, dan Syamsul Falah ${ }^{3}$ \\ ${ }^{1)}$ Program Studi Silvikultur Tropika, Sekolah Pascasarjana IPB, \\ ${ }^{2)}$ Departeman Silvikultur, Fakultas Kekutanan IPB, \\ ${ }^{3)}$ Departemen Biokimia, Fakultas MIPA IPB.
}

\begin{abstract}
Dieback disease by the fungus Botryodiplodia theobromae in Jabon seedlings (Anthocephalus cadamba) inhibits the regeneration of Jabon plant. Synthetic fungicides utilization to several problems such as residue on the environment and pathogen resistance. Chitosan is a potential natural compound used as an alternative to control plant disease.This research aims to examine the effectiveness of chitosan to control $\mathrm{B}$. theobromae as causal agent of dieback on Jabon seedlings and to examine the effect of chitosan to control the viscosity of dieback disease on Jabon seedlings. The results showed that the chitosan solution can decrease the severity of disease in Jabon seedlings. However, it was different with the disease incidence rate parameter. Chitosan solution was not significantly affecting the disease because B. theobromae caused dieback symptoms on Jabon seedlings. The most effective treatment was chitosan solution with a concentration of $0.1 \%$ before inoculation with the severity of the disease by $25 \%$. Chitosan solution viscosity was responsible in affecting the percentage of dieback disease in Jabon seeds. The higher the viscosity of chitosan, the higher the percentage of dieback disease attacks. The best viscosity to suppress the development of dieback disease on Jabon seedlings was 8.80 with $7.90 \%$ attack.
\end{abstract}

Key words: Anthocephalus cadamba, Botryodiplodia theobromae, chitosan, dieback.

\section{PENDAHULUAN}

Jabon merupakan jenis pohon cepat tumbuh yang berpotensi untuk dikembangkan dalam pembangunan hutan tanaman, hutan rakyat, maupun tujuan lain. Pada masa yang akan datang Jabon memiliki peranan penting ketika terjadi penurunan pasokan kayu industri dari hutan alam (Pratiwi 2003). Tanaman ini dapat digunakan sebagai bahan pembuatan peti, papan tipis, korek api, pensil, kayu lapis, serta pulp dan kertas (Wahyudi 2012). Oleh sebab itu, seiring penanaman Jabon secara masal, gangguan penyakit di area pembibitan menjadi salah satu potensi kendala dalam usaha pembibitan tanaman Jabon. Kondisi bibit yang masih sekulen menjadikan tanaman rentan terhadap gangguan penyakit sehingga bibit Jabon di persemaian berpotensi menjadi inang bagi patogen (Aisah et al. 2015). Penyakit yang banyak menyerang bibit Jabon di persemaian yaitu mati pucuk yang disebabkan oleh cendawan Botryodiplodia sp. (Aisah 2014).

Menurut Anggraeni et al. (2011), Botryodiplodia sp. dapat menyerang tanaman kehutanan di Indonesia yang menyebabkan bercak daun pada pulai, merbau, bakau dan makaranga. Selain itu menyebabkan busuk akar pada meranti dan penyakit batang pada gaharu. Aisah (2014) melaporkan bahwa kejadian penyakit dan keparahan penyakit pada bibit Jabon mencapai $100 \%$. Selain itu, Yanti et al. (2015) juga telah melaporkan bahwa kejadian penyakit pada bibit jabon putih dengan perlakuan pelukaan mencapai $100 \%$ dengan tingkat keparahan hingga $62 \%$.

Pengendalian terhadap serangan Botryodiplodia sp. pada tanaman Jabon penting dilakukan untuk menekan kerugian produksi bibit maupun penurunan produktivitas pohon. Pengendalian yang sering dilakukan yaitu menggunakan fungisida sintetik berbahan aktif bahan kimia sepeti mancozeb atau yang lainnya akan memberikan dampak terhadap lingkungan serta menimbulkan residu (Sugipriatini 2009). Adanya residu fungisida pada lingkungan terutama di dalam air yang melebihi ambang batas keamanan untuk air minum dapat membahayakan kehidupan manusia maupun biota air. Penggunaan fungisida sintetik secara berlebih dapat menyebabkan patogen lebih resisten dan beresiko terhadap kesehatan manusia (Lauzardo et al. 2008), sehingga pengendalian Botryodiplodia sp. secara alami sangat dibutuhkan untuk mengurangi kerusakan lingkungan akibat penggunaan fungisida. Pengendalian hayati menjadi alternatif yang lebih aman terhadap manusia dan juga lingkungan (Sharma et al. 2009). Salah satu bahan alam yang berpotensi untuk mengendalikan penyakit tanaman adalah kitosan. Hasri (2010) dan Trisnawati (2013) telah meloporkan bahwa kitosan memiliki sifat biologi dan mekanik yang tinggi diantaranya biorenewable, biodegradable, dan biofungsional sehingga aman untuk lingkungan. 
Kitosan adalah poli-(2-amino-2-deoksi- $\beta$-(1-4)-Dglukopiranosa) dengan rumus molekul $\left(\mathrm{C}_{6} \mathrm{H}_{11} \mathrm{NO}_{4}\right)_{\mathrm{n}}$ (Sugita et al. 2009). Kitosan memperoleh banyak perhatian di bidang pertanian karena bentuk dan sifatnya yang khas dalam menghambat pertumbuhan banyak cendawan patogen dan kemampuannya sebagai ketahanan tanaman (El Gaouth et al. 1992). Beberapa hasil penelitian menunjukkan bahwa pelapisan kitosan pada buah apel, kiwi, pir, stroberi, dan raspberry juga efektif mengendalikan busuk pascapanen pada saat penyimpanan (Banos et al. 2004). Meng et al. (2010) telah melaporkan bahwa kitosan efektif dalam mengendalikan Alternaria kikuchiana dan Physalospora piricola penyebab kerusakan pascapanen buah pir pada konsentrasi $0.1 \%$. Penelitian kitosan dengan konsentrasi 0.1 juga efektif sebagai antifungi Aspergilus niger (Li et al. 2008). Anirban (2013) melaporkan bahwa kitosan efektif dalam mengendalikan persen perkecambahan spora Fusarium solani dengan konsentrasi $0.2 \%$. Selain itu, penyakit busuk buah kakao, kerdil hampa pada padi, busuk akar Fusarium pada tomat, Alfalfa Mosaic Virus, Potato Spindle Tuber Viroid pada daun tomat, dan antraknosa buah pepaya juga dapat dikendalikan dengan kitosan (Nawar 2005). Liu et al. (2006) juga telah menunjukkan bahwa kitosan dapat menghambat perkecambahan spora cendawan patogen penyebab kapang biru pada buah tomat, Penicillium expansum dan Botrytis cinerea secara signifikan. Aplikasi penggunaan kitosan pada komoditas kehutanan terutama Jabon belum banyak dilaporkan, maka perlu dilakukan studi lebih lanjut mengenai keefektifaannya serta aplikasi penggunaannya. Oleh karena itu, dalam penelitian ini dilakukan uji keefektifan kitosan dalam mengendalikan mati pucuk pada bibit Jabon.

\section{BAHAN DAN METODE}

\section{Alat dan Bahan}

Bahan yang digunakan dalam penelitian meliputi: isolat Botryodiplodia theobromae yang diperoleh dari Laboratorium Patologi Hutan Fakultas Kehutanan IPB, larutan kitosan yang diperoleh dari Departemen Teknologi Hasil Perikanan Fakultas Perikanan dan Kelautan IPB, bibit Jabon putih umur 4 bulan, media potato dextrose agar (PDA), aquades, kapas, aluminium foil. Peralatan digunakan dalam penelitian meliputi: autoclave, kabinet Laminar Air Flow, corebore, mikroskop, jarum suntik, termometer, object glass, kompor, panci, gelas ukur $1000 \mathrm{~mL}$, gelas ukur $10 \mathrm{~mL}$, spatula, cawan petri, labu erlenmeyer, sprayer, pipet tetes, timbangan analitik, Viskometer Brookfield, hidrometer.

\section{Prosedur Penelitian}

\section{Penyiapan Larutan Kitosan}

Kitosan cangkang udang dalam bentuk serbuk diperoleh dari Departemen Teknologi Hasil Perikanan, Fakultas Perikanan dan Kelautan IPB. Larutan kitosan $1 \%$ diperoleh dengan melarutkan 1 gram serbuk kitosan dalam $20 \mathrm{~mL}$ asam asetat $1.5 \%$, kemudian ditambahkan aquades hingga mencapai volume $100 \mathrm{~mL}$ (Pranomo 2012).

\section{Uji Viskositas Kitosan dan Penentuan Bobot Molekul}

Uji viskositas relatif $\left(\eta_{\mathrm{r}}\right)$ kitosan dilakukan di Laboratorium PT. Saraswanti Indo Genetech. Sebanyak $500 \mathrm{~mL}$ larutan kitosan dimasukkan ke dalam gelas piala $500 \mathrm{~mL}$. Spindle pada Viskometer Brookfield dicelupkan pada larutan kitosan yang telah disiapkan, kemudian nilai kekentalan diamati pada layar monitor setelah menunjukkan angka yang stabil (Manual book Viskometer Brookfield PT. Saraswanti Indo Genetech). Pengukuran juga dilakukan untuk beberapa konsentrasi kitosan lainnya dengan dua kali ulangan. Nilai yang diperoleh dalam pengukuran merupakan viskositas relatif $\left(\eta_{\mathrm{r}}\right)$ kemudian di konversi menjadi viskositas spesifik $\left(\eta_{\mathrm{sp}}\right)$ dapat dilihat pada Tabel 2. Bobot molekul kitosan dihitung dengan menggunakan rumus MarkHouwink (Yuliana 2011):

$$
\begin{array}{ll} 
& \eta=\mathrm{KM}^{\alpha} \\
\text { Ket: } & \\
\eta & =\text { Viskositas intrinsik }^{-30} \mathrm{DD}^{14} \\
\mathrm{~K} & =1.64 \times 10^{-3)} \mathrm{X} \mathrm{DD}+1.82 \\
\alpha & =\left(-1.02 \times 10^{-2}\right. \\
\mathrm{M} & =\text { Bobot molekul }
\end{array}
$$

\section{Penyiapan Patogen dan Uji Virulensi}

Isolat $B$. theobromae patogen mati pucuk pada bibit Jabon diperoleh dari Laboratorium Patologi Hutan Fakultas Kehutanan IPB. Perbanyakan isolat dilakukan dengan menggunakan media PDA. Sebelum isolat digunakan pada uji efektifitas kitosan, terlebih dahulu dilakukan uji virulensi patogen pada bibit Jabon berumur 4 bulan dengan metode inokulasi blok agar tempel mengacu pada Ismail (2012) dalam Aisah (2014). Isolat $B$. theobromae sebagai sumber inokulum diperoleh dengan cara memotong bagian ujung koloni isolat cendawan umur 7 hari dengan cork borer $(\varnothing 6$ $\mathrm{mm}$ ). Setelah itu, potongan agar ditempel pada batang tanaman bibit Jabon yang telah dilukai dengan jarum suntik. Potongan blok agar yang ditempel pada bagian batang bibit tersebut selanjutnya ditutup dengan kapas lembab dan alumunium foil. Gejala penyakit diamati selama 14 hari setelah inokulasi.

\section{Reisolasi}

Isolasi cendawan dari jaringan tanaman dilakukan berdasarkan metode Akrofi dan Amoah (2009) dalam Aisah (2014) dengan modifikasi pada penggunaan bahan disinfektan untuk sterilisasi permukaan jaringan tanaman. Langkah pertama, jaringan yang memperlihatkan gejala sakit dipotong. Potongan jaringan kemudian disterilisasi permukaan dengan cara direndam dalam larutan alkohol $70 \%$ selama 1 menit, lalu dicuci dengan air steril sebanyak 3 kali, selanjutnya dikeringkan di atas kertas saring steril yang ada di dalam cawan petri. Jaringan tanaman sakit tersebut kemudian dipotong pada bagian antara yang sehat dan sakit, lalu dimasukkan ke dalam cawan petri berisi media PDA (Potato Dextrose Agar). Potongan jaringan 
tanaman pada media PDA selanjutnya diinkubasi selama 7 hari. Koloni miselium yang tumbuh dari potongan jaringan yang diisolasi kemudian dimurnikan dan diperbanyak pada media PDA. Isolat cendawan yang diperoleh selanjutnya digunakan sebagai bahan untuk identifikasi dan sumber inokulum.

\section{Uji Efektivitas Kitosan In-vivo}

Uji efektifitas kitosan dilakukan dengan cara menyemprotkan masing-masing konsentrasi kitosan pada bibit Jabon satu hari sebelum inokulasi dan satu hari setelah inokulasi. Inokulasi dilakukan dengan menggunakan metode penempelan blog agar berdasarkan Yanti (2015) dengan modifikasi. Isolat $B$. theobromae yang digunakan berumur 7 hari. Batang Jabon sehat dilukai dengan jarum suntik steril, kemudian isolat $B$. theobromae pada media tumbuh PDA (diambil menggunakan corebore berdiameter 6 $\mathrm{mm}$ ) ditempelkan pada batang yang telah dilukai dan dilapisi dengan kapas lembab. Potongan agar mengandung patogen yang digunakan adalah kultur berumur 7 hari. Kemudian batang ditutup menggunakan alumunium foil untuk menjamin potongan patogen tidak terlepas selama 14 hari pengamatan. Kelembaban kapas dijaga dengan memberikan beberapa tetes aquades steril setiap hari. Tanaman kontrol diinokulasi dengan blok agar tanpa isolat. Parameter yang diamati adalah kejadian dan keparahan penyakit yang disebabkan oleh $B$. theobromae pada bibit, serta temperatur dan kelembaban udara dalam rumah kaca.

Kejadian penyakit (KjP) pada bibit Jabon dihitung menggunakan rumus sebagai berikut (Rahma 2013) :

$$
\mathrm{KjP}=\frac{a}{\mathrm{~N}} \times 100 \%
$$

Ket:

a = Jumlah tanaman yang bergejala

$\mathrm{N}=$ Jumlah tanaman yang diamati

Keparahan penyakit (KpP) diukur menggunakan rumus Toensend dan Hoeberger dalam Rahma 2013 sebagai berikut :

Ket:

$$
\mathrm{KpP}=\frac{\sum(\text { ni } \times \text { vi })}{\mathrm{Z} \times \mathrm{N}} \times 100 \%
$$

ni $=$ Jumlah tanaman yang terinfeksi dalam setiap kategori

vi $=$ Nilai numerik masing-masing kategori

$\mathrm{N}=$ Jumlah seluruh tanaman yang diamati

$\mathrm{Z}=$ Nilai numerik kategori serangan tertinggi

Nilai numerik dan keparahan penyakit yang digunakan pada penelitian ini disajikan pada Tabel 1 dan Gambar 5.

Tabel 1 Nilai numerik dan keparahan penyakit mati pucuk pada bibit Jabon

\begin{tabular}{cl}
\hline $\begin{array}{c}\text { Nilai } \\
\text { Numerik }\end{array}$ & \multicolumn{1}{c}{ Keterangan Keparahan Penyakit } \\
\hline 0 & Sehat (tidak ada gejala infeksi) \\
1 & $\leq 25 \%$ bagian tanaman mengalami nekrosis \\
2 & $25.1-50 \%$ bagian tanaman mengalami nekrosis \\
3 & $>50 \%$ bagian tanaman mengalami nekrosis \\
4 & Tanaman mati \\
\hline
\end{tabular}

Pengukuran temperatur dan kelembaban dilakukan pada pagi (pukul 06.00-07.00 WIB), siang (pukul 12.0013.00 WIB), dan malam (18.00-19.00 WIB). Pengukuran temperatur dan kelembaban udara bertujuan untuk mengontrol lingkungan agar tanaman Jabon tetap tumbuh pada kondisi optimumnya.

\section{Analisis Data}

Penelitian ini menggunakan rancangan dua faktor dalam rancangan acak lengkap (Faktorial RAL) dengan 5 ulangan. Faktor pertama adalah waktu penyemprotan, yang terdiri atas dua taraf yaitu, sebelum inokulasi (T0) dan setelah inokulasi (T1). Faktor kedua adalah konsentrasi larutan kitosan yang terdiri atas enam taraf $0.0 \%$ (K00), $0.1 \%$ (K01), $0.3 \%$ (K03), $0.5 \%$ (K05), $0.8 \%$, dan $1.0 \%$ (K10). Semua data hasil uji efektifitas larutan kitosan dianalisis dengan selang kepercayaan 95\% menggunakan software SAS 9.3.1. Apabila hasil analisis menunjukkan pengaruh nyata, maka dilanjutkan dengan uji jarak berganda Duncan.

\section{HASIL DAN PEMBAHASAN}

\section{Viskositas dan Bobot Molekul}

Hasil pengukuran viskositas larutan kitosan menunjukkan bahwa semakin tinggi konsentrasi larutan kitosan maka nilai viskositasnya pun meningkat (Tabel 2). Hal ini berarti konsentrasi larutan kitosan berbanding lurus dengan viskositasnya, sehingga konsentrasi larutan kitosan rendah lebih encer dan mudah bergerak, sedangkan konsentrasi larutan kitosan tinggi lebih kental dan sulit bergerak.

Viskositas suatu fluida merupakan daya hambat yang disebabkan oleh gesekan antara molekul-molekul cairan, yang mampu menahan aliran fluida sehingga dapat dinyatakan sebagai indikator tingkat kekentalannya (Warsito et al. 2010). Semakin besar nilai viskositas suatu fluida maka semakin sulit fluida tersebut untuk mengalir dan bergerak. Nilai viskositas dipengaruhi oleh konsentrasi larutan (Yulina 2011), sehingga secara bersama viskositas dan konsentrasi larutan berpengaruh terhadap daya hambat pertumbuhan penyakit mati pucuk pada bibit Jabon.

Hasil perhitungan bobot molekul kitosan yang digunakan dalam penelian ini sebesar $20.6 \mathrm{kDa}$ (Tabel 2). Goy et al. (2009) telah mengklasifikasikan kitosan berdasarkan bobot molekul dibedakan menjadi 3, meliputi kitosan dengan $\mathrm{BM}$ rendah yaitu $<50 \mathrm{kDa}, \mathrm{BM}$ sedang 50-150 kDa, dan BM tinggi yaitu $<150 \mathrm{kDa}$. Berdasarkan klasifikasi tersebut maka kitosan yang digunakan termasak ke dalam kitosan dengan BM rendah, sehingga diharapkan dapat berpengaruh baik dalam menghambat pertumbuhan $B$. theobromae.

Younes (2014) melaporkan tidak ada kecenderungan secara umum bahwa aktivitas antifungi kitosan berhubungan dengan peningkatan atau penurunan BM, tetapi tergantung jenis fungi tertentu. Namun, sebagian besar penelitian yang telah dilakukan menyimpulkan bahwa kitosan dengan BM rendah lebih efektif dalam menghambat pertumbuhan fungi maupun bakteri. BM kitosan berpengaruh terhadap ukuran molekul kitosan, 
oleh karena itu kitosan dengan BM rendah memiliki ukuran molekul yang lebih kecil. Hal ini berpengaruh terhadap kemampuan kitosan BM rendah dalam menembus rongga dinding sel sehingga dapat menghambat metabolisme sel jamur, sedangkan kitosan dengan BM tinggi tidak dapat menembus rongga dinding sel, akibatnya kitosan BM tinggi hanya dapat berinteraksi dengan dinding sel jamur (Li et al. 2008).

Tabel 2 Viskositas larutan kitosan dan bobot molekul

\begin{tabular}{cccc}
\hline Konsentrasi $(\%)$ & $\eta_{\mathrm{r}}(\mathrm{cP})$ & $\eta_{\mathrm{sp}}$ & $\mathrm{BM}(\mathrm{kDa})$ \\
\hline 0.00 & 2.82 & 1.82 & 20.6 \\
0.10 & 4.80 & 3.80 & \\
0.30 & 6.48 & 5.48 & \\
0.50 & 9.06 & 8.06 & \\
0.80 & 13.26 & 12.26 & \\
1.00 & 15.30 & 14.30 & \\
\hline
\end{tabular}

\section{Uji Efektifitas Kitosan terhadap Pengendalian Mati} Pucuk Bibit Jabon oleh Cendawan B. theobromae

Semua bibit Jabon yang diinokulasikan B. theobromae menunjukkan gejala mati pucuk, sehingga dapat dikatakan tingkat kejadian penyakit pada bibit Jabon sebesar 100\%. Hasil tersebut menunjukkan pemberian larutan kitosan tidak berpengaruh nyata dalam mengurangi tingkat kejadian penyakit. Akan tetapi, pemberian larutan kitosan mempengaruhi tingkat keparahan penyakit (Tabel 3).

Tabel 3 Pengaruh konsentrasi larutan kitosan terhadap keparahan penyakit pada bibit jabon

\begin{tabular}{lcc}
\hline Konsentrasi (\%) & $\eta_{\mathrm{sp}}$ & $\mathrm{KpP}(\%)$ \\
\hline 0.00 & 1.82 & $75.20^{\mathrm{a}}$ \\
0.10 & 3.80 & $7.90^{\mathrm{c}}$ \\
0.30 & 5.48 & $23.70^{\mathrm{c}}$ \\
0.50 & 8.06 & $29.10^{\mathrm{bc}}$ \\
0.80 & 12.26 & $51.00^{\mathrm{ab}}$ \\
1.00 & 14.30 & $57.30^{\mathrm{a}}$ \\
\hline
\end{tabular}

Konsentrasi larutan kitosan yang digunakan dalam penelitian ini yaitu $0.00,0.10,0.30,0.50,0.80$, dan 1.00 $\%$ dengan masing-masing keparahan penyakit mati pucuk pada bibit Jabon sebesar 75.20, 7.90, 23.70, 29.10, 51.00, dan 57.30\%. Kitosan mampu menghambat perkembangan mati pucuk bibit Jabon secara nyata pada konsentrasi $0.10 \%$ dengan tingkat keparahan $7.90 \%$. Perlakuan yang paling efektif yaitu pemberian larutan kitosan konsentrasi $0.1 \%$ sebelum dilakukan inokulasi dengan tingkat keparahan penyakit sebesar 25\%, sedangkan bibit Jabon tanpa penyemprotan larutan kitosan memiliki tingkat keparahan penyakit hingga $80 \%$ (Tabel 5). Hal ini diduga terkait dengan viskositas larutan kitosan. Tingginya konsentrasi larutan kitosan menyebabkan tingkat kekentalan larutan yang tinggi sehingga kemampuan mengalirnya lebih rendah.

Tabel 4 Pengaruh waktu penyemprotan terhadap keparahan penyakit mati pucuk pada bibit Jabon

\begin{tabular}{lc}
\hline Waktu Penyemprotan & $\mathrm{KpP}(\%)$ \\
\hline Sebelum inokulasi & $31.10^{\mathrm{a}}$ \\
Setelah inokulasi & $50.30^{\mathrm{b}}$ \\
\hline
\end{tabular}

Waktu penyemprotan dilakukan satu hari sebelum dan setelah inokulasi. Berdasarkan hasil pengamatan, waktu efektif penyemprotan larutan kitosan dilakukan sebelum inokulasi. Bibit Jabon dengan penyemprotan kitosan sebelum inokulasi mengalami keparahan penyakit mati pucuk sebesar $31.10 \%$, sedangkan bibit Jabon dengan penyemprotan kitosan setelah inokulasi mengalami keparahan penyakit sebesar 50.30\% (Tabel 4). Dengan demikian waktu penyemprotan larutan kitosan sebelum inokulasi lebih baik dalam menghambat perkembangan penyakit mati pucuk pada bibit Jabon dibandingkan dengan penyemprotan larutan kitosan setelah inokulasi. Hal ini sesuai dengan hasil penelitian Simanjuntak (2012) mengenai pengaruh kitosan terhadap penyakit kerdil hampa pada tanaman padi yaitu efektif pada perlakuan penyemprotan sebelum inokulasi mampu menghambat keparahan penyakit hingga $40.74 \%$.

Tabel 5 Kejadian dan keparahan penyakit

\begin{tabular}{lll}
\hline Perlakuan & $\mathrm{KjP}(\%)$ & $\mathrm{KpP}(\%)$ \\
\hline T0K00 & 100 & $80^{\mathrm{a}}$ \\
T0K01 & 100 & $25^{\mathrm{e}}$ \\
T0K03 & 100 & $25^{\mathrm{e}}$ \\
T0K05 & 100 & $40^{\mathrm{de}}$ \\
T0K08 & 100 & $50^{\mathrm{cde}}$ \\
T0K10 & 100 & $60^{\mathrm{abcd}}$ \\
T1K00 & 100 & $80^{\mathrm{a}}$ \\
T1K01 & 100 & $30^{\mathrm{de}}$ \\
T1K03 & 100 & $55^{\mathrm{abcd}}$ \\
T1K05 & 100 & $45^{\mathrm{bcde}}$ \\
T1K08 & 100 & $70^{\mathrm{abc}}$ \\
T1K10 & 100 & $75^{\mathrm{abc}}$ \\
\hline
\end{tabular}

Perlakuan yang paling efektif yaitu pemberian larutan kitosan konsentrasi $0.1 \%$ sebelum dilakukan inokulasi dengan tingkat keparahan penyakit sebesar $25 \%$, sedangkan bibit Jabon tanpa penyemprotan larutan kitosan memiliki tingkat keparahan penyakit hingga $80 \%$ (Tabel 5). Beberapa penelitian dengan konsentrasi lebih rendah menunjukkan bahwa semakin meningkatnya konsentrasi larutan maka daya hambat terhadap pertumbuhan penyakit semakin besar pula (Hamdayanty 2012), namun dalam penelitian ini menunjukkan bahwa peningkatan konsentrasi tidak selalu meningkatkan daya hambat terhadap perkembangan patogen. Megasari et al. (2013) melakukan penelitian mengenai pengaruh kitosan terhadap penularan Bean common mosaic virus pada kacang panjang dengan konsentrasi paling efektif 0.3 dan $0.5 \%$, sedangkan pada konsentrasi lebih tinggi mengalami penurunan aktivitas antimikroba. Hal ini diduga terkait dengan viskositas larutan kitosan. Tingginya konsentrasi larutan kitosan menyebabkan tingkat kekentalan larutan yang tinggi sehingga kemampuan mengalirnya lebih rendah. Nurainy et al. (2008) menyatakan bahwa kosentrasi larutan kitosan yang rendah lebih mudah berdifusi pada media agar. 

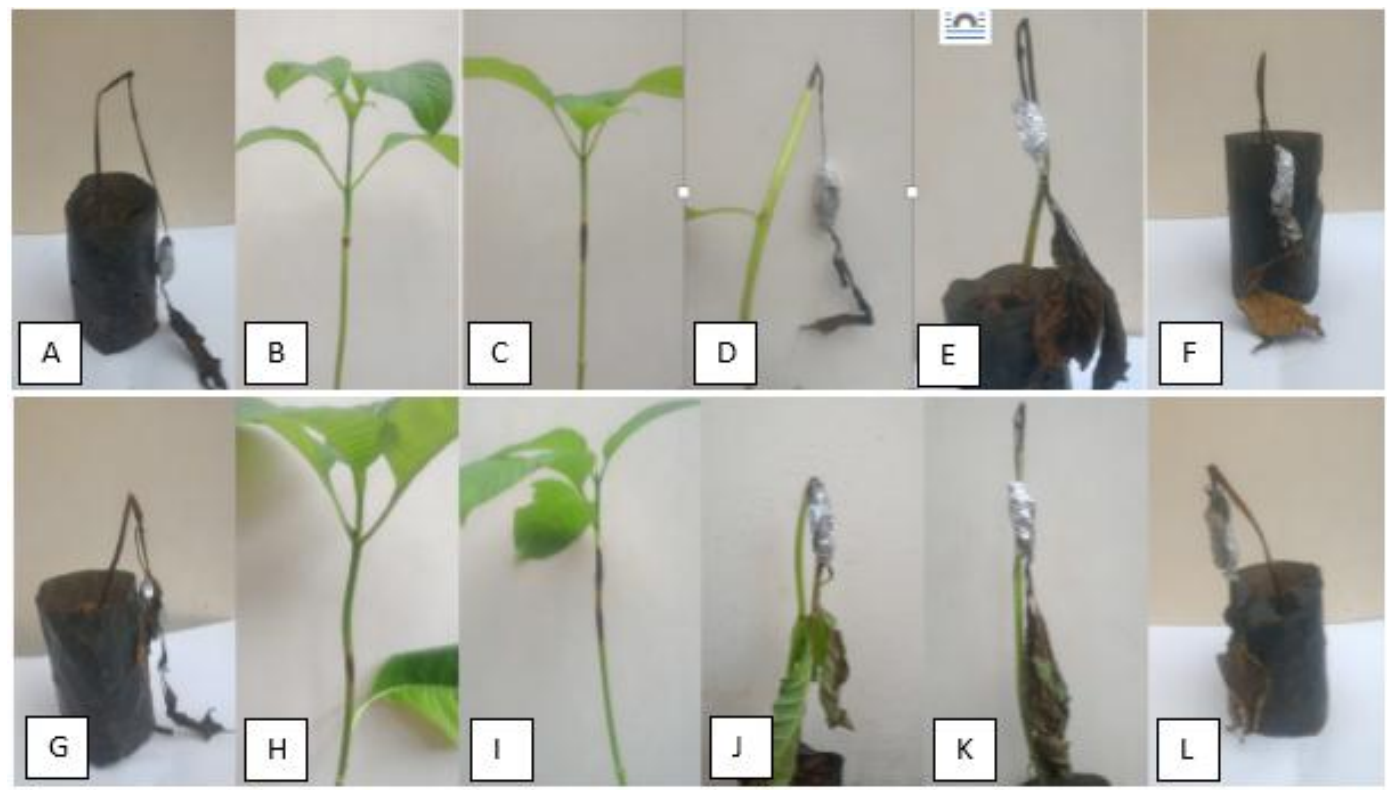

Gambar 1 Keparahan penyakit pada bibit Jabon. (a)T0K00, (B)T0K01, (C)T0K03, (D)T0K05, (E)T0K08, (F)T0K10, (G)T1K00, (H)TIK01 , (I)TIK03 , (J)TIK05 , (K)TIK08, (L)TIK10

Hingga saat ini, ada tiga kemungkinan mekanisme kitosan sebagai antifungi. Pertama, interaksi kitosan dengan muatan negatif fosfolipid membran sel yang mengakibatkan peningkatan permeabilitas sel dan menyebabkan kebocoran isi sel (Chatterje et al. 2014). Kitosan memiliki gugus fungsional amina $\left(-\mathrm{NH}_{2}\right)$ bermuatan positif yang sangat reaktif, sehingga mampu berikatan dengan dinding sel yang bermuatan negatif. Kedua, kitosan berperan dalam mengikat elemen tertentu sehingga beberapa nutrisi penting tidak tersedia dan pertumbuhannya menjadi tidak normal. Gugus $\left(-\mathrm{NH}_{2}\right)$ juga memiliki pasangan elekton bebas, maka gugus ini dapat menarik mineral $\mathrm{CA}^{2+}$ yang terdapat pada dinding sel dengan membentuk ikatan kovalen koordinasi (Killay 2013, Trisnawati et al. 2013). Ketiga, penetrasi kitosan ke dalam dinding sel dan berinteraksi dengan DNA sehingga berpengaruh terhadap produksi protein dan enzim penting (Younes 2014).

\section{Temperatur dan Kelembaban}

Perkembangan penyakit didukung oleh tiga faktor, yaitu inang yang rentan, patogen yang virulen, dan lingkungan yang mendukung. Kondisi lingkungan merupakan bagian penting bagi perkembangan penyakit, seperti temperatur dan kelembaban. Hasil rata-rata pengukuran temperatur pada penelitian ini yaitu $25.6{ }^{\circ} \mathrm{C}$ pada pagi hari, $31.1{ }^{0} \mathrm{C}$ pada siang hari, dan $26.4{ }^{0} \mathrm{C}$ pada malam hari (Tabel 6). Rataan kelembaban berkisar $91.1 \%$ pada pagi hari, siang $78.7 \%$, dan malam $86.9 \%$. Temperatur tersebut merupakan temperatur optimum bagi pertumbuhan $B$. theobromae sehingga luas serangan mati pucuk pada bibit Jabon mencapai $100 \%$ dan cukup parah. Hal ini sesuai dengan hasil penelitian Kausar et al. (2009) menyatakan bahwa, $25 \pm 2{ }^{\circ} \mathrm{C}$ merupakan temperatur optimum pertumbuhan miselium Lasiodiplodia theobromae dan F. Solani. Selain itu, Penelitian Sato et al. (2008) juga menunjukkan bahwa L. theobromae tumbuh optimal pada temperatur $30{ }^{\circ} \mathrm{C}$. Menurut Martawijaya et al. (1989), bahwa temperatur maksimum pertumbuhan Jabon berkisar $32-42{ }^{\circ} \mathrm{C}$ dan temperatur minimum berkisar $3-15.5{ }^{\circ} \mathrm{C}$. Selama 14 hari pengamatan, kondisi lingkungan berada pada kisaran temperatur optimum dalam mendukung pertumbuhan bibit, sehingga gejala yang terjadi merupakan akibat serangan patogen, bukan faktor abiotik yang berasal dari temperatur atau kelembaban udara sekitar bibit.

Tabel 6 Temperatur dan kelembaban

\begin{tabular}{ccccccc}
\hline \multirow{2}{*}{ Hari ke- } & \multicolumn{3}{c}{ Temperatur $\left({ }^{\circ} \mathrm{C}\right)$} & \multicolumn{3}{c}{ Kelembaban $(\%)$} \\
\cline { 2 - 7 } & Pagi & Siang & Malam & Pagi & Siang & Malam \\
\hline 0 & 27 & 31 & 26 & 89 & 72 & 86 \\
2 & 26 & 32 & 26 & 91 & 77 & 87 \\
3 & 25 & 29 & 27 & 94 & 82 & 85 \\
4 & 25 & 31 & 28 & 91 & 83 & 85 \\
5 & 27 & 30 & 27 & 91 & 83 & 86 \\
6 & 25 & 32 & 26 & 91 & 81 & 86 \\
7 & 25 & 31 & 26 & 93 & 81 & 86 \\
8 & 27 & 31 & 27 & 89 & 73 & 88 \\
9 & 26 & 32 & 26 & 91 & 67 & 87 \\
10 & 27 & 32 & 25 & 92 & 75 & 92 \\
11 & 23 & 29 & 26 & 88 & 86 & 85 \\
12 & 25 & 33 & 27 & 92 & 83 & 88 \\
13 & 25 & 32 & 26 & 92 & 81 & 87 \\
14 & 26 & 31 & 26 & 91 & 78 & 88 \\
\hline Rata-rata & 25.6 & 31.1 & 26.4 & 91.1 & 78.7 & 86.9 \\
\hline
\end{tabular}

\section{KESIMPULAN}

Pemberian larutan kitosan dapat menekan keparahan penyakit mati pucuk yang disebabkan oleh cendawan $B$. theobromae pada bibit Jabon. Konsentrasi optimum larutan kitosan dalam mengendalikan penyakit mati pucuk pada bibit Jabon yaitu $0.1 \%$. Waktu penyemprotan larutan kitosan terbaik dilakukan sebelum inokulasi patogen. Interaksi faktor konsentrasi dan waktu penyemprotan larutan kitosan tidak berpengaruh nyata terhadap keparahan penyakit mati pucuk pada bibit Jabon. 
Viskositas larutan kitosan berpengaruh dalam menekan perkembangan penyakit mati pucuk pada bibit Jabon. Nilai viskositas lebih rendah memberikan efek lebih baik dalam menekan keparahan penyakit. Viskositas larutan kitosan yang efektif dalam menekan keparahan penyakit mati pucuk pada bibit Jabon yaitu 3.80 .

\section{DAFTAR PUSTAKA}

Aisah AR. 2014. Identifikasi dan patogenitas cendawan penyebab primer penyakit mati pucuk pada bibit jabon (Anthocephalus cadamba (Roxb.) Miq) [tesis]. Bogor (ID): Institut Pertanian Bogor.

Aisah AR, Soekarno BPW, Achmad. 2015. Isolasi dan identifikasi cendawan yang berasosiasi dengan penyakit mati pucuk pada bibit jabon (Anthocephalus cadamba (Roxb.) Miq). Jurnal Penelitian Hutan Tanaman. 12(3): 153-163.

Anggraeni I, Lelana NI. 2011. Diagnosis Penyakit Tanaman Hutan. Haneda NF, Rahayu S, editor. Bogor (ID): Pusat Litbang Peningkatan Produktivitas Hutan.

Anirban. 2013. Fungicidal potencial of chitosan against phytopathogenic Fusarium solani. Journal of Experimental Biology and Sciences.

Banos SB, Lauzardoa ANH, Vallea MHL, Barkab EA, Molinac EB, Wilsond CL. 2004. Chitosan as a potential natural compound to control pre and postharvest diseases of horticultural commodities. Crop Prot. [Internet]. [diunduh 2012 Sept 14];25(2006):108-118. Tersedia pada: http://www.sciencedirect.com/science/article/pii/ S0261219405001110.

Chatterje S, Chatterje BP, Guha AK. 2014. A study on antyfungal activity of water soluble chitosan against Macrophomina paseolina. Internasional Journal of Biological Macromolecules. 67:452457. doi:10.1016/j.ijbimac.2004.04.008.

El Gaouth A, Arul J, Asselin A, Benhamou N. 1992. Antifungal activity of chitosan on post-harvest pathogens: induction of morphological and cytological alterations in Rhizopus stolonifer. Mycol Res. 9:769-779. doi:10.1016/S09537562(09)80447-4.

Goy RC, Douglas B,Odilio BGA. 2009. A review antimicrobial activity of chitosan. J Polymer 19:1-7.

Hamdayanty, Yunita R, Amin NN, Damayanti TA. 2012. Pemanfaatan kitosan untuk mengendalikan antraknosa pada pepaya (Colletrotichum gloeosporioides) dan meningkatkan daya simpan buah. J Fitopatol Indones. 8(4):97-102.

Hasri. 2010. Prospek kitosan dan kitosan termodifikasi sebagai biopolimer alami yang menjanjikan. Jurnal Chemica. 11(2):1-10.

Kausar P, Sobia C, Rashida P. 2009. Physiological studies on Lasiodiplodia theobromae and Fusarium solani: the cause of Shesham decline. Mycopath 7(1): 35-38.
Killay A, Nurpudji A, Suryani A, Meta M. 2015. Chitosan as antimicrobial agent and fatty acid absorber in smoked skipjack tuna processed using coconut shell. American Journal of Life Sciences. 3(2):93-99. doi: 10.11648/j.ajls.20150302.16.

Lauzardo ANH, Banos SB, Valle MGV, Montealvo M, Rifera MMS, Perez LAB. 2008. Antifungal effects of chitosan with different moleculas weight on in vitro development of Rhizopus stolonifer. J Carbohydrate Polymers. 73:541547. doi:10.2016/j.carbpol.2007.12.020.

Li. 2008. Effects of molecular weight and concentration of chitosan on antifungal activity against Aspergilus niger. Iranian Polymer Jornal. 17(11):843-852.

Liu J, Tian S, Meng X, Xu Y. 2006. Effects of chitosan on control of postharvest diseases and physiological responses of tomato fruit. Postharv Biol Tech. [Internet]. [diunduh 2012 Sept 14];44(2007):300-306. Tersedia pada:http://tianlab.ibcas.ac.cn/04fbwz/2007/liujia -2007-PBT.pdf.

Martawijaya A, Kartasujana I, Mandang YI, Prawira SA, Kadir K. 1989. Atlas Kayu Indonesia Jilid II. Bogor: Pusat Penelitian dan Pengembangan Hasil Hutan Bogor.

Megasari D, DamayantiTA, Santoso S. 2014. Pengendalian Aphis craccivora Koch. dengan kitosan dan pengaruhnya terhadap penularan Bean common mizaic virus starin Black eye cowpea (BCMV-BIC) pada kacang panjang. Jurnal Entomologi Indonesia. 11(2):72-80. Doi:10.5994/jei.11.2.72.

Meng X, Yang L, Kennedy JF, Tian S. 2010. Effects of chitosan and oligo chitosan on growth of two fungal pathogens and physiological properties in pear fruit. Elsevier. 81:7075.doi:10.1016/j.carbpol.2010.01.057.

Nurainy F, Rizal S, Yudiantoro. 2008. Pengaruh konsentrasi kitosan terhadap aktivitas antibakteri dengan metode difusi agar (sumur). Jurnal Teknologi Industri dan Hasil Pertanian. 12(2):117-125.

Nawar LS. 2005. Chitosan and three Trichoderma spp. to control Fusarium crown and root rot of tomato in Jeddah, Kingdom Saudi Arabia. Egypt $J$ Phytopathol. [Internet]. [diunduh 2012 Sept 14];33(2005):45-58. Tersedia pada: http://www.onasseef.kau.edu.sa/Files/195/Resear ches/5620026534.pdf.

Pratiwi. 2003. Prospek Pohon Jabon untuk Pengembangan Hutan Tanaman. Buletin Penelitian dan Pengembangan Kehutanan 4(1):62-66.

Pranomo E, Prabowo PSA, Purnawan C, Wulansari J. 2012. Pembuatan dan karakterisasi kitosan vanilin sebagai membran polimer elektrolit. Jurnal Penelitian Kimia. 8(1):70-78.

Rahma H. 2013. Penyakit layu stewart (Pantoea stewartii subsp. Stewartii) pada jagung dan upaya pengendaliannya [disertasi]. Bogor(ID): Institut Pertanian Bogor. 
Sato T, Yumi I, Keisuke T, Satoshi T, Atsushi O, Kazaku T. 2008. Black band of Jew's marrow caused by Lasiodiplodia theobromae. J Gen Plant Pathol 74:91-93.doi:10.1007/s10327-0070056-2.

Sharma RR, Dinesh S, Rajbir S. 2009. Biological control of postharvest diseases of fruits and vegetables by microbial antagonists: A review. Biol Contr. [Internet]. [diunduh 2012 Desember 17];50(2009): 205-221. Tersedia pada:http://www.sciencedirect.com/science/articl e/pii/S10499644090012-36.

Sugipriatini D. 2009. Potensi penggunaan khamir dan kitosan untuk pengendalian busuk buah Lasiodiplodia theobromae (Pat.) Griffon \& Maubl. (syn. Botryodiplodia theobromae Pat.) pada buah mangga selama penyimpanan [tesis]. Bogor(ID): Institut Pertanian Bogor.

Sugita P, Sjahtiza TWA, Wahyono D. 2009. Kitosan Sumber Biomaterial Masa Depan. Bogor(ID): IPB Press.

Trisnawati E, Andesti D, Saleh A. 2013. Pembuatan kitosan dari limbah cangkang kepiting sebagai bahan pengawet buah dukudengan variasi lama pengawetan. Jurnal Teknik Kimia. 2(19):17-26.

Wahyudi. 2012. Analisis pertumbuhan dan hasil tanaman jabon (Anthocephalus cadamba).

Yanti LA. 2015. Uji resistensi bibit jabon putih dan merah (Anthocephalus spp.) terhadap serangan Botryodiplodia theobromae penyebab penyakit mati pucuk [tesis]. Bogor (ID): Institut Pertanian Bogor.

Yanti LA, Achmad, Khumaida N. 2015. Uji resistensi bibit jabon (Anthocephalus spp.) terhadap Botryodiplodia theobromae (Pat.) penyebab mati pucuk. J. Silvikultur Tropika. 6(2):83-92.

Younes I, Sellimi S, Rinaudo M, Jellouli K, Moncef N. 2014. Influence of acetilation degree and molecular weight of homogenous chitosans on antibacterial and antifungal activities. International Journal of Food Microbiology. 130. doi:10.2016/j.jifoodmicro.2014.04.029.

Yuliana IK. 2011. Aktivitas antibakteri kitosan berdasarkan perbedaan derajat deasetilasi dan bobot molekul [tesis]. Bogor (ID): Institut Pertanian Bogor. 